$\mathcal{H a l}: 27-33$

\title{
PENGARUH KEMAMPUAN AWAL TERHADAP KECEMASAN MATEMATIKA SISWA DI SMP DI TINJAU DARI PEMBELAJARAN MATERI BERHITUNG DENGAN PENDEKATAN PMR
}

\author{
Rahma Muti'ah ${ }^{1}$ dan Irmayanti² \\ 1,2Dosen Pendidikan Matematika STKIP Labuhan Batu \\ Jalan SM Raja No. 126 A, Aek Tapa, Rantauprapat ${ }^{1,2}$ \\ rmuthea5@gmail.com 1 dan r.irmayanti@yahoo.com²
}

\begin{abstract}
Abstrak
Siswa yang memiliki kecemasan belajar matematika tinggi umumnya disebabkan karena ketidak mampuan mereka mengerjakan matematika bagaimanapun usaha mereka. Semakin mereka berusaha untuk menjawab pertanyaan guru atau soal yang diberikan mereka semakin merasakan pusing, mual dan berkeringat. Sehingga ketika menghadapi soal mereka lebih memilih untuk melihat pekerjaan teman, atau bahkan tidak mengerjakan soal tersebut sama sekali dan mempersiapkan diri untuk menerima hukuman atau sanksi dari guru. Berdasarkan hal tersebut maka tujuan dari penelitian ini adalah untuk melihat pengaruh kemampuan awal matematika siswa terhadap kecemasan matematika siswa SMP di Kecamatan NA IX X Kabupaten Labuhanbatu Utara Propinsi Sumatera Utara. Sampel dalam penelitian ini adalah SMP Negeri 1 NA IX X dan SMP Negeri 2 NA IX X yang diperoleh dengan teknik random. Teknik pengumpulan data adalah dengan menggunakan Tes kemampuan awal, angket kecemasan matematika dan observasi di kelas. Analisis data yang digunakan adalah analisis regresi sederhana, dengan melihat hasil uji F, uji t dan uji determinan dari kedua variabel. Hasil dari penelitian ini adalah ada pengaruh antara kemampuan awal matematika terhadap kecemasan matematika dengan arah pengaruh adalah negatif yang artinya jika kemampuan awal matematika meningkat maka kecemasan matematika siswa cenderung akan menurun, namun jika kemampuan awal matematika menurun maka kecemasan matematika siswa akan meningkat. Dengan persamaan regresi adalah $Y=32.370-0.288 X$. dengan besaran pengaruh antar variabel adaah $25.90 \%$.
\end{abstract}

\section{Kata Kunci : Kemampuan Awal Matematika, Kecemasan Matematika}

\section{Pendahuluan}

SMP Negeri 1 NA IX $X$ dan SMP Negeri 2 NA IX $X$ adalah sekolah negeri yang berada di wilayah Kabupaten Labuhanbatu Utara. Berdasarkan hasil penelitian pendahulu dengan mengukur tingkat kecemasan matematika siswa dan hasil belajar siswa diperoleh, ada beberapa siswa yang memiliki hasil belajar rendah karena memiliki kecemasan belajar matematika yang tergolong sedang dan bahkan ada yang tergolong tinggi. Matematika sebagai salah satu ilmu dasar memegang peranan penting dalam berbagai aspek kehidupan manusia, baik untuk keperluan praktis sehari- hari maupun untuk perkembangan ilmu pengetahuan. Kebanyakan siswa berpandangan bahwa Matematika sulit untuk dipelajari dan didukung juga oleh pandangan masyarakat umum sehingga mata pelajaran Matematika cenderung dihindari oleh para siswa yang mengalami kesulitan belajar. Siswa mengalami kecemasan ketika berhadapan dengan pelajaran Matematika di sekolah. Kecemasan ini bila ditanggapi positif oleh siswa akan memberikan dorongan bagi mereka untuk belajar lebih giat lagi. Tapi sebaliknya bila ditanggapi negatif oleh siswa maka pelajaran Matematika akan semakin dijauhi dan tidak diminati.

Padahal Matematika adalah ilmu yang harus dipelajari secara bertahap dan sifatnya akumulatif. Siswa yang tidak paham pada tahapan tertentu akan mengalami kesulitan untuk beranjak ke tahapan berikutnya. Tindakan yang sering dilakukan untuk menangani masalah kesulitan belajar tersebut antara lain:

1. Sekolah inisiatif memberikan jam 
pelajaran tambahan di luar jam pelajaran sekolah. Kendala biasanya pada ketersediaan jam pengajar di sekolah;

2. Mengikutsertakan siswa pada kegiatan bimbingan belajar yang dikelola oleh lembaga formal atau pribadi. Kendala biasanya pada kemampuan keuangan orang tua untuk membiayai karena relatif mahal ;

3. Siswa belajar di rumah dibantu oleh kakaknya atau orang tua. Kendala biasanya kakak sibuk dengan beban sekolahnya sedangkan orang tua tidak memahami pelajaran anaknya di sekolah dengan baik bahkan sering terjadi kesalah pahaman antara orangtua dengan anaknya

Dari hasil wawancara dengan siswa yang memiliki kecemasan belajar matematika tinggi, penyebab utama mereka mengalami rasa cemas karena mereka berpikir bahwa mereka tidak akan mampu mengerjakan matematika bagaimanapun usaha mereka. Semakin mereka berusaha untuk menjawab pertanyaan guru atau soal yang diberikan mereka semakin merasakan pusing, mual dan berkeringat. Sehingga ketika menghadapi soal mereka lebih memilih untuk melihat pekerjaan teman, atau bahkan tidak mengerjakan soal tersebut sama sekali dan mempersiapkan diri untuk menerima hukuman atau sanksi dari guru.

Mereka berpikir bahwa bagaimanapun belajar matematika mereka adalah orangorang yang memang "bodoh" dalam matematika dan bagaimanapun mereka berusaha mereka tidak akan bisa mempelajari atau memahami matematika dan hanya orang-orang yang memang pintar yang mampu untuk mengerjakan matematika. Selain itu mereka juga merasa bahwa soal-soal matematika sangat sulit untuk dipahami. Ada juga siswa yang mengeluhkan kesulitan memahami matematika karena dia menilai guru matematika mereka sangat "garang" (suka marah-marah dan serius ketika mengajar) yang membuat suasana kelas menjadi sangat tegang dan ini membuat dirinya sulit untuk berkonsentrasi mendengarkan mengerti persamaan linier (pengetahuan mengerti persamaan kuadrat bila ia belum prasyarat belum ada), (Ruseffendi, 2006). penjelasan dari guru. Siswa lain mengatakan bahwa tidak jarang guru hanya memberikan soal lalu meminta siswa untuk menyelesaikannya tanpa terlebih dahulu guru menjelaskan bagaimana cara mengerjakannya, siswa diminta untuk belajar mandiri dengan melihat contoh yang ada di buku pegangan.

Untuk mengcrosscek hasil wawancara dengan siswa, maka peneliti melakukan observasi dengan melihat langsung bagaimana cara guru matematika mengajar di kelas. Pada umumnya cara guru mengajar dikelas adalah dengan cara menuliskan dan menjelaskan contoh soal, lalu memberi kesempatan kepada siswa untuk bertanya, ketika siswa tidak ada yang bertanya maka guru langsung memberikan soal untuk dikerjakan siswa, kemudian guru meninggalkan siswa di kelas dan berpesan untuk mengantar lembar jawaban siswa ke ruang guru. Kondisi siswa ada yang terlihat tegang dan ada juga yang hanya bersikap apatis tidak peduli dan sibuk mengerjakan hal lain. Ketika guru pergi para siswa mengerjakan soal dengan meminta atau menyalin pekerjaan teman mereka yang mereka rasa adalah orang yang paham dengan soal tersebut.

Salah satu faktor internal yang dapat mempengaruhi keberhasilan peserta didik dalam belajar matematika adalah kemampuan awal peserta didik. Kemampuan awal peserta didik merupakan faktor penentu dalam keberhasilan pembelajaran matematika. Setiap individu mempunyai kemampuan belajar yang berlainan. Kemampuan awal peserta didik adalah kemampuan yang telah dipunyai oleh peserta didik sebelum ia mengikuti pembelajaran yang akan diberikan. Kemampuan awal (entry behavior) ini menggambarkan kesiapan peserta didik dalam menerima pelajaran yang akan disampaikan oleh guru. Keberhasilan peserta didik dalam suatu pelajaran atau pendidikan juga tergantung dari kesiapan anak. Kesiapan anak ini ada dua macam, perkembangan mentalnya sudah siap dan pengetahuan prasyaratnya sudah dimiliki. Peserta didik belum bisa mengerti berhitung bila ia belum dapat memahami banyaknya (perkembangan mentalnya belum siap) dan ia tidak akan 
Perbedaan kemampuan awal siswa akan mempengaruhi tingkat penguasaan materi bahan pelajaran antara masingmasing siswa. Selain itu, kemampuan awal juga sangat menentukan dalam proses berpikir siswa dalam memahami dan mengetahui sebuah masalah yang diberikan. Kemampuan awal yang baik akan dapat menuntun siswa untuk lebih mudah dalam memahami persoalan matematika yang melibatkan kemampuan

\section{Metode Penelitian}

Metode yang digunakan dalam penelitian ini adalah penelitian Deskriptif Kunatitatif dengan jenis penelitian deskriptif assosiatif untuk melihat pengaruh dua variabel yaitu variabel kemampuan awal matematika dan kecemasan matematika. Pendekatan penelitian yang digunakan dalam penelitian ini adalah penelitian kuantitatif dengan jennis penelitian asosiatif yang bertujuan untuk mengetahui hubungan antara dua variabel atau lebih (Ade Djohar Mauridi, 2014).

\section{Lokasi penelitian}

Adapun lokasi dalam penelitian ini adalah di SMP Negeri 1 NA IX X Aek Kota Batu Kec. NA IX X Kabupaten Labuhanbatu Utara dan SMP Negeri 2 NA IX X Sei Raja Kec. NA IX X Kabupaten Labuhanbatu Utara.

\section{Populasi dan Sampel}

Populasi dalam penelitian ini adalah seluruh SMP yang ada di Kabupaten Labuhanbatu Utara, sedangkan sampel adalah siswa SMP Negeri 1 NA IX $X$ dan SMP Negeri 2 NA IX X yang berjumlah 466 siswa.

\section{Alat Pengumpul Data}

Data dalam penelitian ini diperoleh dari pemberian Tes kemampuan awal matematika, angket kecemasan berpikir tingkat tinggi. Siswa yang memiliki kemampuan awal yang baik, tentunya memiliki potensi untuk melakukan proses berpikir tingkat tinggi atau berpikir kritis, karena telah memiliki pondasi pengetahuan yang cukup untuk melakukan olah pikir yang baik. Berdasarkan hal tersebut maka tujuan dari penelitian ini adalah untuk melihat pengaruh kemampuan awal matematika terhadap kecemasan matematika siswa.

matematika dan observasi perilaku kecemasan matematika siswa di kelas selama proses pembelajaran.

\section{Analisis Data}

Teknik analisis data yang digunakan dalam penelitian ini adalah uji regresi linier berganda. Dimana sebelum melakukan uji regresi terlebih dahulu melakukan analisis asumsi klasik yang terdiri dari 1) uji normalitas, 2) uji multikolinieritas, 3) uji heteroskedastisitas, dan 4) uji autokorelasi. Setelah dilakukan uji asumsi klasik langkah berikutnya adalah uji hipotesis dengan mengggunakan persamaan 1) uji parsial (uji t), 2) uji F dan 3) uji Determinasi.

\section{Hasil Penelitian Dan Pembahasan}

Pada kegiatan ini dilakukan untuk mengukur seberapa pengaruh kemampuan awal terhadap kecemasan matematika, yang dilihat dari hasil skor uji pengaruh kemampuan awal siswa dengan kecemasan matematika siswa di SMP Negeri 1 dan 2 NA IX X di Kota Batu pada saat screening test dengan jumlah siswa adalah 466 yang terdiri dari 321 siswa SMP Negeri 1 NA $X X$ dan 147 siswa SMP Negeri 2 NA IX X. Adapun nilai kemampuan awal matematika siswa diperoleh hasil sebagai berikut:

\begin{tabular}{|c|c|c|c|}
\hline No & Skor Rata-Rata & Kategori & Jumlah \\
\hline 1 & $X \geq 73$ & Tinggi & 33 \\
\hline 2 & $61 \leq X<73$ & Sedang & 99 \\
\hline 3 & $X<60 \quad$ Rendah & 334 \\
\hline \multicolumn{2}{|c|}{ Jumlah } & 466 \\
\hline
\end{tabular}

Tabel 1 : nilai kemampuan awal matematika siswa

Dari tabel diatas terlihat bahwa dari 466 siswa yang dijadikan sampel dalam penelitian ini, diperoleh hasil bahwa siswa yang memiliki kemampuan awal matematika yang tinggi dalam berhitung berjumlah 33 siswa, dan ada 99 siswa yang memiliki kategori kemampuan awal matematika dalam taraf sedang, sedangkan 
Hal : $27-33$

ada 334 siswa yang memiliki tingkat kemampuan awal matematika dalam persoalan berhiitung yang masih dalam kategori rendah. Ini membuktikan bahwa kemampuan awal matematika siswa dalam berhitung umumnya masih dalam kategori rendah. Dibawah ini akan ditampilkan diagram batang dari hasil analisis data kemampuan awal matematika dalam berhitung :

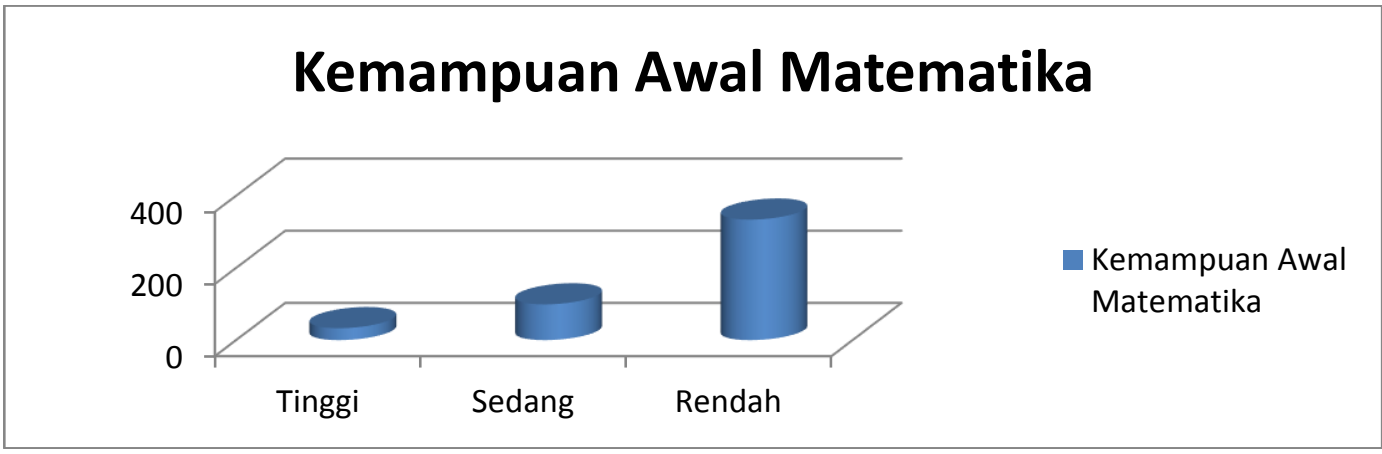

Gambar 1 : diagram batang kemampuan awal matematika siswa

Sedangkan hasil perhitungan skor untuk kecemasan matematika akan diperlihatkan dibawah ini:

\begin{tabular}{|c|l|c|c|}
\hline No & Skor Rata-Rata & Kategori & Jumlah \\
\hline 1 & $\mathrm{X} \geq 23$ & Tinggi & 125 \\
\hline 2 & $11 \leq \mathrm{X}<23$ & Sedang & 243 \\
\hline 3 & $\mathrm{X}<11$ & Rendah & 98 \\
\hline \multicolumn{2}{r|}{ Total } & 466 \\
\hline
\end{tabular}

Tabel 2 : nilai kecemasan matematika siswa

Dari tabel diatas terlihat bahwa dari 466 siswa 98 siswa memiliki tingkat kecemasan dalam kategori rendah, dan
243 siswa dalam kategori kecemasan sedang dan 125 siswa masih memiliki tingkat kecemasan yang tinggi.

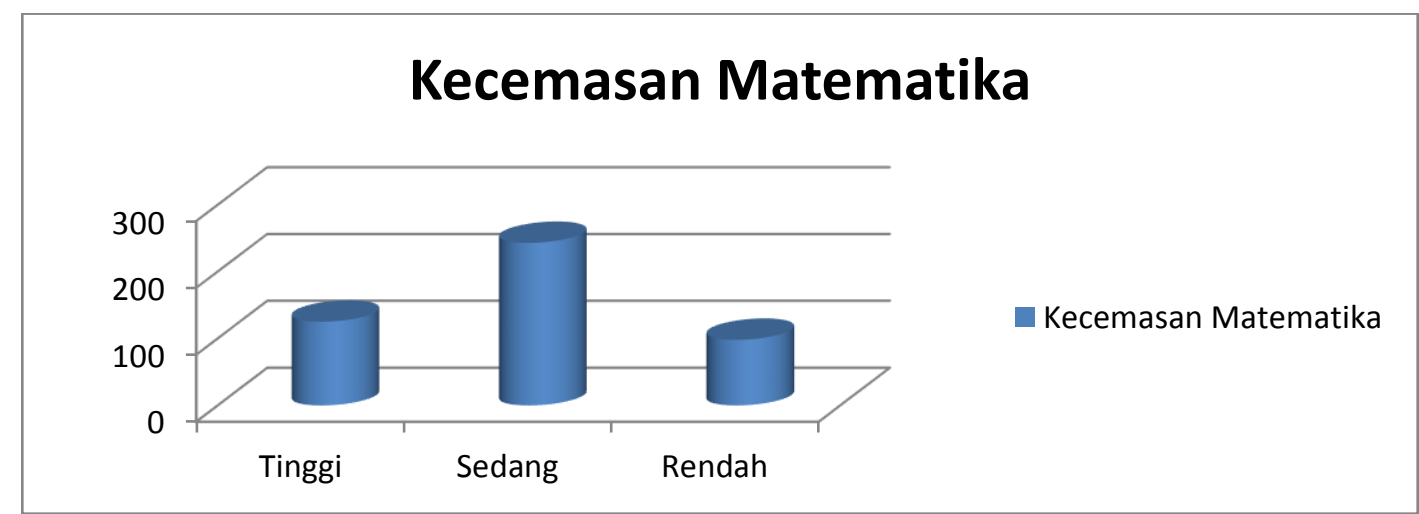

Gambar 2 : Diagram batang kecemasan matematika siswa

Sebelum melakukan uji hipotesis maka dilakukan uji normalitas pada masing-

masing data yaitu:

\begin{tabular}{|l|c|c|}
\hline \multicolumn{1}{|c|}{ Kelas } & $\begin{array}{c}\text { Kolmogorov } \\
\text { Smirnov (sig.) }\end{array}$ & Kesimpulan \\
\hline Kemampuan Awal & 0.000 & Normal \\
\hline Kecemasan Matematika & 0.000 & Normal \\
\hline
\end{tabular}

Tabel 3 : hasil uji normalitas 
Tabel diatas menunjukkan bahwa nilai signifikansi dari kecemasan matematika $0.000<0.05$. signifikansi kemampuan awal $0.000<0.05$, nilai signifikansi dari hasil perhitungan data tersebut membuktikan bahwa keseluruhan data yang diajukan dalam penelitian ini memiliki distribusi normal sehingga dapat dilanjutkan untuk melakukan analisis berikutnya.

Correlations

\begin{tabular}{|rl|r|r|}
\hline & & kemampuan & kecemasan \\
\hline \multirow{5}{*}{ kemampuan } & Pearson Correlation & 1 &,$- 510^{* *}$ \\
& Sig. (2-tailed) & &, 000 \\
& $\mathrm{~N}$ & 466 & 466 \\
& Pearson Correlation &,$- 510^{\star *}$ & 1 \\
kecemasan &, 000 & \\
& Sig. (2-tailed) & 466 & 466 \\
& $\mathrm{~N}$ & &
\end{tabular}

Tabel 4 : Hasil uji korelasi

Dari hasil output diatas terlihat nilai korelasi antara kemampuan awal matematika siswa dengan kecemasan matematika siswa bernilai -0.510 dengan nilai sig $0.000<0.05$. Ini membuktikan bahwa ada hubungan antara kemampuan awal matematika siswa terhadap kecemasan matematika siswa walaupun kuatnya hubungan masih dalam kategori cukup atau sedang yaitu sebesar 0.510. arah hubungan korelasi antara kemampuan awal dan kecemasan matematika adalah negatif, ini diartikan bahwa jika kemampuan awal matematika siswa meningkat maka kecemasan matematika siswa akan menurun, begitu juga jika kemampuan awal matematika siswa menurun maka kecemasan matematika siswa akan meningkat. Dapat disimpulkan bahwa siswa yang memiliki kecemasan matematika umumnya dikarenakan memiliki kemampuan awal matematika yang rendah sebelum mengikuti pembelajaran matematika.

Model Summary

\begin{tabular}{|c|c|c|c|c|c|c|c|c|c|}
\hline \multirow[t]{2}{*}{ Model } & \multirow[t]{2}{*}{$\mathrm{R}$} & \multirow[t]{2}{*}{ R Square } & \multirow{2}{*}{$\begin{array}{l}\text { Adjusted } \\
\text { R Square }\end{array}$} & \multirow{2}{*}{$\begin{array}{l}\text { Std. Error } \\
\text { of the } \\
\text { Estimate }\end{array}$} & \multicolumn{5}{|c|}{ Change Statistics } \\
\hline & & & & & $\begin{array}{c}\text { R Square } \\
\text { Change }\end{array}$ & $\begin{array}{c}\mathrm{F} \\
\text { Change }\end{array}$ & df1 & df2 & $\begin{array}{l}\text { Sig. F } \\
\text { Change }\end{array}$ \\
\hline 1 &, $510^{\mathrm{a}}$ & ,260 & 259 & 6,910 & 260 & $\begin{array}{r}163,15 \\
6\end{array}$ & 1 & 464 & ,000 \\
\hline
\end{tabular}

a. Predictors: (Constant), kemampuan

Dari hasil output diatas terlihat nilai Adjusted R Square adalah 0.259, ini berarti bahwa kemampuan awal matematika siswa dalam mempengaruhi kecemasan matematika adalah sebesar $25.90 \%$ sedangkan $74.10 \%$ masih banyak yang dipengaruhi oleh faktor-faktor lain, misalkan seperti faktor guru, faktor metode pembelajaran, karakter atau kepribadian siswa dan lain-lain.

ANOVA $^{a}$

\begin{tabular}{|l|r|r|r|r|r|}
\hline \multicolumn{1}{|c|}{ Model } & Sum of Squares & \multicolumn{1}{c|}{ df } & Mean Square & F & Sig. \\
\hline Regression & 7791,030 & 1 & 7791,030 & 163,156 &, $000^{\mathrm{b}}$ \\
1 & 22156,997 & 464 & 47,752 & & \\
Residual & 29948,028 & 465 & & & \\
\hline
\end{tabular}

a. Dependent Variable: kecemasan

b. Predictors: (Constant), kemampuan

Dari hasil perhitungan nilai $F$ terlihat nilai sig $0.000<0.05$ ini membuktikan bahwa ada pengaruh antara kemampuan awal matematika siswa terhadap kecemasan matematika siswa. 
Coefficients $^{a}$

\begin{tabular}{|c|c|c|c|c|c|c|c|c|c|c|}
\hline \multirow[t]{2}{*}{ Model } & \multicolumn{2}{|c|}{$\begin{array}{l}\text { Unstandardized } \\
\text { Coefficients }\end{array}$} & $\begin{array}{c}\text { Standardized } \\
\text { Coefficients }\end{array}$ & \multirow[t]{2}{*}{$\mathrm{t}$} & \multirow[t]{2}{*}{ Sig. } & \multicolumn{3}{|c|}{ Correlations } & \multicolumn{2}{|c|}{$\begin{array}{l}\text { Collinearity } \\
\text { Statistics }\end{array}$} \\
\hline & $B$ & $\begin{array}{l}\text { Std. } \\
\text { Error }\end{array}$ & Beta & & & $\begin{array}{l}\text { Zero- } \\
\text { order }\end{array}$ & $\begin{array}{l}\text { Parti } \\
\text { al }\end{array}$ & Part & $\begin{array}{c}\text { Tolera } \\
\text { nce }\end{array}$ & $\begin{array}{l}\mathrm{VI} \\
\mathrm{F}\end{array}$ \\
\hline (Constant) & 32,370 & 1,254 & & 25,805 & 000 & & & & & \\
\hline${ }^{1}$ kemampuan &,- 288 & ,023 &,- 510 & 12,773 &, 000 &,- 510 &,- 510 &,- 510 & 1,000 & $\begin{array}{r}1,0 \\
00\end{array}$ \\
\hline
\end{tabular}

Untuk pengujian nilai t diperoleh nilai sig $0.000<0.05$ ini membuktikan ada pengaruh antara kemampuan awal matematika terhadap kecemasan matematika dengan arah pengaruh adalah negatif yang artinya jika kemampuan awal matematika meningkat maka kecemasan matematika siswa cenderung akan menurun, namun jika kemampuan awal matematika menurun maka kecemasan matematika siswa akan meningkat. Dengan persamaan regresi adalah $\mathrm{Y}=32.370-$ $0.288 X$.

Dalam pelaksaksanaan pembelajaran matematika rendahnya kemampuan awal yang dimiliki siswa dapat menjadi awal siswa kehilangan minat belajar karena kesulitan dalam menyelesaikan masalah serta minimnya pengetahuan awal yang dimilikinya. Jika hal ini dibiarkan maka siswa akan berpikir bahwa pembelajaran menjadi sia-sia, sebagai akibatnya akan muncul perasaan tidak nyaman, cemas, gelisah, jenuh dan merasa tidak mampu menyelesaikan permasalahan matematika yang diberikan. Perasaan tersebut yang disebut sebagai kecemasan matematika atau Matematics Anxiety. Kecemasan merupakan bagian dari kehidupan manusia sehari-hari dan gejala yang normal. Setiap orang cenderung pernah merasakan kecemasan pada saat-saat tertentu, dan dengan tingkat yang berbeda-beda.

\section{Kesimpulan Dan Saran}

Dalam upaya mengatas kecemasan $\mathrm{m}$ atematika seorang guru harus lebih memperhatikan kemampuan awal matematika siswa, ini karena siswa yang memiliki kemampuan awal matematika yang rendah akan memicu peningkatan kecemasan matematika siswa dalam pembelajarna matematika. Ini terlihat dari hasil analisis pengaruh kemampuan awal matematika siswa terhadap kecemasan matematika siswa ditemukan bahwa siswa yang memiliki kemampuan awal matematika yang tinggi akan memiliki kecemasa matematika yang rendah dengan nilai besarnya pengaruh adalah $25.90 \%$. untuk itu sebaiknya guru lebih memperhatikan kemampuan awal matematika siswa sebelum memberikan materi pembelajaran matematika. Selain itu berupaya untuk terlebih dahulu meningkatkan kemampuan awal matematika siswa sebelum melanjutkan kegiatan pembelajaran. Hal ini berguna agar tingkat kemampuan awal matematika siswa tidak mempengaruhi kecemasan matematika siswa yang pada akhirnya akan membuat siswa mengalami kesulitan belajar matematika di kelas.

\section{Daftar Rujukan}

Anita, Ika Wahyu. 2014. Pengaruh Kecemasan Matematika (Mathematics Anxiety) Terhadap Kemampuan Koneksi Matematis Siswa SMP. Jurnal. Infinity Jurnal IImiah Program Studi Pendidikan Matematika STKIP Siliwangi Bandung, Vol. 3 No.1 Februari 2014.

Ekawati, Aminah. 2015. Pengaruh Kecemasan Terhadap Hasil Belajar Matematika Siswa Kelas VII SMP Negeri 13 Banjarmasin. Jurnal. Math Didactic: Jurnal Pendidikan Matematika. ISSN 2442-3041. Vol. 1 No. 3 September-Desember 2015.

Ellis, Albert. 2006. Rational Emotive Behavioral Approaches to Childhood Disorders. Theory, Practice and Research. USA : Springer

Hariyanti, Desi Dwi. 2013. Penerapan Konseling Kelompok Rational Emotive Behaviour Untuk Meningkatkakn Motivasi Belajar Siswa Kelas VIII G SMP Yayasan Pendidikan 17 Surabaya. Jurnal. 
Jurnal BK UNESA, Volume 01 Nomor 01 Tahun 2013, 0-216.

Irmayanti. 2013. Peningkatan Kemampuan Pemecahan Masalah dan Self Efficacy Matematis Siswa SD Melalui Pendekatan Matematika Realistik. Thesis tidak diterbitkan. Medan : Sekolah Pascasarjana Universitas Negeri Medan.

Munasiah. 2015. Pengaruh Kecemasan Belajar dan Pemahaman Konsep Matematika Siswa Terhadap Kemampuan Penalaran Matematika. Jurnal. Jurnal formatif 5 (3) : 220232, 2015 ISSN : 2088-351X.

Muti'ah, Rahma. 2014. Pengaruh Kecerdasan Emosional Siswa
Terhadap Kecemasan Belajar Matematika. Jurnal. Jurnal Eduscience ISSN 2303- 355x Vol.2 No. 1 Oktober $2014 \mathrm{Hal}$; 32-43.

Muhlisin, N. Dantes dan Sariyasa. 2013. Pengaruh Pendekatan Pembelajaran Matematika Realistik Terhadap Hasil Belajar Matematika Ditinjau dari Tingkat Kecemasan Belajar Siswa. Jurnal. E-journal program pascasarjana Universitas Pendidikan Ganesha Vol. 3 tahun 2013.

Wicaksono, Arief Budi dan M. Saufi. 2013. Mengelola Kecemasan Siswa Dalam Pembelajaran Matematika. Prosiding. ISBN : 978-979-16353-9-4. 